\title{
CONSTITUTIONALITY OF MECHANISM APPROVAL GOVERNMENT REGULATION REPLACEMENT ACT IN LAW NUMBER 12 OF 2011 CONCERNING THE FORMATION OF LAWS AND REGULATIONS
}

\author{
M Ilham F Putuhena \\ National Legal Development Agency, Ministry of Law and Human Rights \\ m.ilham.f.putuhena@gmail.com
}

\begin{abstract}
The issue of the mechanism for the approval of the laws and regulations needs to be assessed for their constitutionality because it will deal with the authority of the President and the House of Representatives (DPR) in the formation of legislation. The method used in this legal research is the normative juridical method. The results showed that the unconstitutionality of Article 52 and Article 71 of Law 12 of 2011 was because there was a reduction in the authority of the DPR in the Perpu made by the President because the DPR did not yet have the authority to refuse all or accept a portion of the Perpu with conditions for improvement.
\end{abstract}

Keyword: Constitutional, Perpu, DPR, President.

Copyright@2020 NLR.All right reserved.

\section{INTRODUCTION}

Government Regulations in Lieu of Law (Perpu) is one of the products of legislation in Indonesia. In Article 7 paragraph (1) of Law No. 12 of 2011 concerning Formation of Regulations and Regulations (Law 12 of 2011). Regulates that the types and hierarchy of statutory regulations consist of:

a. The 1945 Constitution of the Republic of Indonesia;

b. Decree of the People's Consultative Assembly;

c. Government Act / Regulation in Lieu of Law;

d. Government regulations;

e. Presidential decree;

f. Provincial Regional Regulations; and

g. Regency / City Regulations.

In practice, Perpu has been used by all presidents in Indonesia. During President Soekarno's administration, the total number of Perpu established during President Soekarno's administration in the 4 periods of constitution was 144 Perpu. $^{1} 4$ constitutional periodisations apply as follows: ${ }^{2}$

${ }^{1}$ Of the 144 Perpu that was formed, it can be classified as per these regulations governing the fields of security, economic, legal, social, and political defense, there are $8 \mathrm{Perpu}$ in the defense and security sector, 94 in the economic sector, 19 in the legal sector, 7 in the social sector and in the political sphere there are 16 Perpu, This shows that the matter of urgency that is generally compelling in terms of economics, See Yuliani, Andi,, Artikel Hukum Tata Negara dan PeraturanPerundang-undangan Peraturan Pemerintah Pengganti Undang-Undang dari masa ke masa, http://ditjenpp,kemenkumham,go,id/htn-danpuu/3000-peraturan-pemerintah-pengganti-undang-undang-dari-masa-ke-masa,html, accessed on 18 May (2020).

${ }^{2}$ Ibid. 


\section{LAW REVIEW E-ISSN:2722-3663

1. The 1945 Constitution period after independence (1945-1949) was formed by 17 Perpu.

2. Constitutional Period RIS ((19491950) was formed 6 a regulation which time Mr. Assaad as acting President of the Republic of Indonesia which is still valid region of the RIS 1945.

3. but only in the area of the section. President Sukarno as President of the RIS form 32 Emergency Law since the Constitution RIS only knows the Emergency Law.

4. During the 1950 Constitution (19501959) 145 Emergency Laws were established

5. During the re-enactment period of the 1945 Constitution (1959-1967)

121 Perpu were formed.

During President Soeharto's reign, 8 Perpu were formed. The regulations are classified as regulating the social, economic and legal fields. The tendency in the field of regulation in the Perpu during the Soeharto era was in the economic field. This shows that coercive interests generally concern the economy. During the administration of President Habibie, 3 (three) Perpus were formed, these Perpus were classified as stipulating in these regulations governing the political and legal fields. This shows that coercive interests are generally related to politics. During the reign of President Wahid as many as 3 Perpu and all set the economic field. This shows that the Forced Importance of the Perps formed was only in the field of Economics. During the administration of President Megawati Sukarnoputri 4 (four) Perpus were formed. 2 Perpu in 2002 and 2 Perpu in 2004. During the reign of President SBY In total there were 19 Perpu established during the reign of President SBY. ${ }^{3}$

President Joko Widodo for the term of 2014 - 2020. 6 Perpu. $^{4}$

The Perpu is based on Article 22 of the 1945 Constitution of the Republic of Indonesia (1945 Constitution) which in paragraph (1) regulates that in matters of compulsion, the President has the right to determine government regulations in lieu of laws. Then in paragraph (2) stipulates that the Government Regulation must obtain the approval of the House of Representatives in the following trial. And if it does not get approval, then the government regulation must be revoked regulated in paragraph (3).

Then the procedure for the discussion of the Perpu is regulated in Article 52 of Law 12 of 2011 that the Government Regulation in lieu of the Law must be submitted to the Parliament in the following trial. ${ }^{5}$ That is the first session of the DPR after the Government Regulation in lieu of the Law is determined. ${ }^{6}$ Then it is regulated that the Submission of a Government

\footnotetext{
${ }^{3}$ Article 52 paragraph (3) of Law 12 of 2011.

${ }^{3}$ Article 52 paragraph (4) of Law 12 of 2011.

${ }^{3}$ Article 52 paragraph (5) of Law 12 of 2011.

${ }^{3}$ Covering the political sector by 6 Perpu, the economic field by 5 Perpu, the social field by 5 Perpu, and the legal field by 3 Perpu, the tendency for the regulation to be established is in the political, economic and social fields, so that it can be prematurely concluded that the matters of Interest that force with regard to these fields., Ibid.

${ }^{4}$ The Perpu is 1. Perpu No.1 of 2015. 2. Perpu No. 1 of 2016. 3. Government Regulation No. 1 of 2017. 4. Government Regulation No. 2 of 2017. 5. Perpu No. 1 of 2020. 6. Government Regulation No. 2 of 2020.

${ }^{5}$ Article 52 paragraph (1) of Law 12 of 2011.

${ }^{6}$ Elucidation of Article 52 of Law 12 of 2011 .
} 
Regulation in lieu of a Law is carried out in the form of submission of a Draft Law concerning the stipulation of a Government Regulation in Lieu of a Law into a Law. ${ }^{7}$ And DPR only gives approval or does not give approval to Government Regulations in lieu of Laws. ${ }^{8}$ If obtaining the approval of the DPR in a plenary session, the Government Regulation in Lieu of the Law is stipulated as a Law. ${ }^{9}$ And if the DPR is not approved by the plenary meeting, the Government Regulation in lieu of the Act must be revoked and must be declared invalid. ${ }^{10}$

With the mechanism in Law 12 of 2011, the DPR is only given the choice whether to accept or not to accept the Perpu. The procedure is certainly legally problematic because in the Perpu there are many potentially problematic

articles as opposed to the 1945 Constitution of the Republic of Indonesia because the regulation has the same substance as the law namely implementing the 1945 Constitution of the Republic of Indonesia. Whereas on the one hand the need for a Perpu may be as a about forced coercion. This regulation causes the House of Representatives (DPR) as a representative institution of the people to not be able to carry out the role of the formation of the Law as stipulated in Article 20 paragraph (1) of the 1945 NRI Constitution. So that the legislative authority is the authority of the House of Representatives not the president although the president can submit a bill. Then in Article 20 paragraph (2) of

\footnotetext{
${ }^{7}$ Article 52 paragraph (2) of Law 12 of 2011.

${ }^{8}$ Article 52 paragraph (3) of Law 12 of

2011.

${ }^{9}$ Article 52 paragraph (4) of Law 12 of

2011.

${ }^{10}$ Article 52 paragraph (5) of Law 12 of 2011.
}

the 1945 Constitution of the Republic of Indonesia regulates that each draft law is discussed by the House of Representatives and the President for mutual agreement. So if there are articles that are considered problematic, of course the DPR can make corrections to the article.

Based on these problems, the authors consider it necessary to conduct an assessment of the Constitutionality Mechanism of Approval of Government Regulations in lieu of Laws in Law 12 of 2011 concerning Formation of Regulations and Regulations.

\section{METHODOLOGY}

This study uses the method juridical normative, view problem Constitutionality Approval Mechanism of Government Regulation in Lieu of Law in Law 12 of 2011 on the Establishment Regulation Legislation. According to Peter Mahmud Marzuki, normative legal research is a process to find a rule of law, legal principles and legal doctrines to

answer the legal issues at hand. ${ }^{11}$ Simply stated Soerjono Soekanto argues that normative legal or normative legal research is literature law research conducted by examining library material or secondary data. ${ }^{12}$

This study was carried out using a statute approach which is connected with a conceptual approach. Legal materials obtained in this study were analyzed through a qualitative approach namely research procedures that produce descriptive analytical data from what is obtained in writing, so that the data can be examined and studied to

${ }^{11}$ Marzuki. Peter Mahmud., Penelitian Hukum. (Jakarta: Kencana Prenada Media Group. 2005). p. 93.

${ }^{12}$ Soekanto. S. Mamudji. S., Penelitian Hukum Normatif. (Jakarta: Raja GrafindoPersada. 2006). p. 15. 
analyze the research objects intact in depth in a comprehensive manner, so that in the end can understand and understand aspects of the object of research. ${ }^{13}$ This research is also supported by literature by studying and studying theories, concepts and regulations relating to issues, such as international conventions. ${ }^{14}$ This research will gather various laws and court decisions related to the Constitutionality Mechanism of Approval of Government Regulations in lieu of Laws in Act 12 of 2011 concerning the Formation of Legislation.

\section{DISCUSSION}

\section{Perpu Legal Politics in MK Decision}

Decision of

Constitutional Court (MK) Number 138 / PUU-VII / 2009 in its consideration explained that the 1945 Constitution of the Republic of Indonesia NRI distinguishes between the Perpu and Government Regulations as referred to in Article 5 paragraph (2) whose purpose is to carry out the Act accordingly. Since Government Regulations in lieu of Laws are regulated in the Chapter on DPR while the DPR is the holder of power to form laws, the Perpu material should be material which according to the Constitution is regulated by Law and not material that implements the Act as referred to in Article 5 paragraph (2) the 1945 Constitution and the Perpu material is also not the material of the Constitution.

If there is a vacancy in the Law due to various things so that the material of the Law has not been processed to become an Act in

109.

${ }^{13}$ Marzuki. Peter Mahmud., Op. Cit. p.

145. accordance with the procedures or provisions in force in making the Law, but there are situations and conditions that are urgent that require the rule of law, then the Article 22 of the 1945 Constitution provides special institutions by authorizing the President to make Government Regulations (as) Substitute for the Law. The making of laws to fill the legal vacuum by forming laws as a normal or normal process, starting with the filing of a bill by the Parliament or by the President, will take a long time so that the urgent legal needs cannot be addressed;

In the Constitutional Court Decision Number 003 / PUU-III / 2005, the Constitutional Court emphasized that the "matters of urgency" referred to in Article 22 paragraph (1) are not the same as the "danger situation" as referred to in Article 12 of the 1945 Constitution ${ }^{15}$ and its provisions in Law (Prp) No. 23 of 1959 concerning the State of Danger that must be based on objective conditions as stipulated by law;

According to the Constitutional Court, "matters of urgency that force" referred to in Article 22 paragraph (1) of the 1945 Constitution are indeed the President's subjective rights which will then become objective if approved by the Parliament to be stipulated as a law; that in the practice of state administration so far, the various Perpu issued by the President show that there is a tendency to interpret "matters of urgency" as a state of urgency that needs to be regulated by regulations at the level of the law.

that although the "matters of urgency that compel" the consideration

15 Article 12 of the 1945 Constitution of the Republic of Indonesia regulates the President declaring a danger. The conditions and consequences of a hazard are determined by law. 
of issuing a Perpu the reasons are subjective, in the future, the reasons considered by the President to issue a Perpu should be based more on the objective conditions of the nation and state reflected in the considerations "Considering" from the Perpu concerned.

Then the Constitutional Court gave the objective conditions to the Constitutional Court Decision No. 138 / PUU-VII / 2009, the Court stressed that a Perpu was needed if:

1. the existence of a situation that is the urgent need to resolve legal issues quickly based on the Law;

2. The required law does not yet exist so that there is a legal vacuum, or there is a law but it is not adequate;

3. the legal vacuum cannot be overcome by making the Act in an ordinary procedure because it will require quite a long time while the urgent situation needs certainty to be resolved;

The Constitutional Court is of the opinion that the three conditions above are conditions for forced coercion as referred to in Article 22 paragraph (1) of the 1945 Constitution of the Republic of Indonesia.

So that the notion of "urgency that compels" is not limited to the existence of a danger situation as referred to in Article 12 of the 1945 Constitution of the Republic of Indonesia. It is true that the danger situation as referred to in Article 12 of the 1945 Constitution of the Republic of Indonesia can cause the normal or normal process of forming an Act to be implemented. However, the state of danger is not the only condition that causes the emergence of an urgent force as referred to

in Article 22 paragraph (1) of the 1945 Constitution.
Because Article 22 paragraph (1) of the 1945 Constitution stipulates that government regulations in lieu of Laws, which means that the material should be regulated in the Act of law but because of urgency, the 1945 Constitution of the Republic of Indonesia gives the President the right to establish a Perpu and does not give rights to the Parliament to make regulations in lieu of the Act. If the regulation is handed over to the DPR, the process in the DPR requires quite a long time because the DPR as a representative body, the decision is in the hands of the members, which means to decide on something must go through DPR meetings so that if you have to wait for the DPR's decision on legal needs quickly may not be fulfilled. In certain cases where the need for a law is very urgent to solve a very important state problem felt by all nations, the right of the President to stipulate a

Perpu can even be mandated by the President to establish a Perpu as an effort to resolve the nation and state's problems .

\section{Practice a regulation in $\mathrm{N}$ egara $\mathrm{L}$ ain}

The author tries to present aspects of the practice of the implementation of Perpu in other countries so that it can present a broader context as best practice for examining the regulation of Perpu in Indonesia. According to Fitra Arsil's study, the term is termed a Constitutional decree authority (CDA) in presidential system countries conceptually it can be mentioned as the constitutional power of the president to issue regulations which have binding capacity and material content at the level of the law, issued under certain conditions and immediately apply without any conditions. through a discussion process 
in the legislature. However, although the regulation is effective immediately but it is temporary because it requires parliamentary approval to be enforced as a law or revoked. ${ }^{16}$

With regard to the practice of using the Perpu from Fitra Arsil's opinion, it can be concluded that there are several causative conditions, namely, First, the president's legislative power in various presidential countries is often used by the president to bypass the discussion in parliament in the formation of policies. ${ }^{17}$

Second, it allows divided government to occur, ${ }^{18}$ executive and legislative relations take place in a confrontational manner. The president's attitude continued to issue a Perppu rather than as a solution to overcome these conditions even worsening executive and legislative relations. One that is phenomenal to illustrate the breakdown of executive and legislative relations and the issuance of the Perppu was during the 32nd President of Brazil, Fernando Affonso Collor De Mello. De Mello issued no less than 36 Perppu in the first 15 days in office and around 160 Perppu throughout 1990. De Mello really wanted to run his government by avoiding the legislative process. The

16 Arsil. Fitra., Menggagas Pembatasan Pembentukan Dan Materi Muatan Perppu: Studi Perbandingan Pengaturan dan Penggunaan Perppu di Negara-Negara Presidensial. Jurnal Hukum \& Pembangunan. 48. No. 1 Fakultas Hukum Universitas Indonesia. (2018).

${ }^{17}$ Ibid., p 2.

18 The condition of divided government is a situation of instability in a presidential system that can occur when the president's party is not a majority in parliament (minority president) and the president fails to form a cohesive majority coalition. Vide Arsil, Fitra., Teori Sistem Pemerintahan: Pergeseran Konsep dan Saling Kontribusi Antar Sistem Pemerintahan di Berbagai Negara. (Depok: Rajawali Press, 2017). p. 185.
Perppus that he issued meant that he did not need to be involved in the legislative process in making policies. De Mello is an example of a president who feels that the power given by the constitution is enough to govern without legislative support. De Mello thinks building support in the legislature will limit his autonomy in making policy. ${ }^{19}$

Third, the president's power in the legislative field (Perpu) has made the president a party making policy initiatives and even controlling the agenda in the legislature. Having power in the legislative field enables the president to attract members of parliament to work together to become his supporters.

Through the Perppu which is the proactive power of the president, the president wants to lead and even control the agenda in parliament. The second situation is certainly easier for the president to do in conditions of high political support in parliament. Presidents who have large powers in the legislative field, especially proactive power, tend to have a large bargaining position in parliament. The president can display this power to gain broader political support. ${ }^{20}$ Figuerido and Limongi opinion that presidential power in the legislative field such as the issuance of regulation has not only used in emergencies such as the opinions expressed other experts. ${ }^{21}$

Based on this study, it is found that the formation of the Perpu is not only due to subjective or objective reasons for the resident, but also because of the political relations that occur so that the existence of the Perpu can weaken the legislature (DPR) in

\footnotetext{
${ }^{19}$ Op. Cit., p. 7-8.

${ }^{20}$ Ibid., p 9-10.

${ }^{21}$ Ibid., p 9.
} 


\section{LAW REVIEW E-ISSN:2722-3663

carrying out its main functions. Especially when the Parliament is given the authority of Article 52 of Law 12 of 2011 only to give approval or not give approval to Government Regulations in lieu of law. ${ }^{22}$

\section{Limitation of DPR's Authority in Perpu Approval}

The important thing to discuss next is how the authority of the DPR in the field of legislation on Perpu. Whether the DPR

can fully exercise its authority or have limited authority.

Article 22 paragraph (2) and Paragraph (3) of the 1945 Constitution of the Republic of Indonesia regulates the role of the DPR in relation to the Perpu, that the Perpu must obtain the approval of the House of Representatives in the following trial. And if it doesn't get approval, then the government regulation must be revoked.

The 1945 Constitution of the Republic of Indonesia uses the words "Agreement" and "does not obtain approval" as a form of attitude which becomes the choice of the DPR. Further regulation in Article 52 of Law 12 of 2011 that the Government Regulation in lieu of the Act must be submitted to the Parliament in the following trial. ${ }^{23}$ Then it is regulated that the Submission of a Government Regulation in lieu of a Law is carried out in the form of submission of a Draft Law concerning the stipulation of a Government Regulation in Lieu of a Law into a Law. ${ }^{24}$ And the DPR only gives its approval or does not give its approval to

\footnotetext{
${ }^{22}$ Article 51 Paragraph (3).

${ }^{23}$ Article 52 paragraph (1) of Law 12 of 2011.

${ }^{24}$ Article 52 paragraph (2) of Law 12 of 2011 .
}

the Government Regulation in Lieu of the Law. ${ }^{25}$

The same settings though even more brief also stipulated in Articl e 71 of Law No. 17 of 2014 on the People's Consultative Assembly, House of Representatives, Regional Representatives Council, and Regional House of Representatives (Act 17 of 2014) that the House of Representatives authorized them to form enactment legislation discussed with the President to obtain mutual agreement and give approval or not give approval to government regulations in lieu of laws proposed by the President to become law. ${ }^{26}$

Then in Article71 paragraph (1) and paragraph (2) of Law 12 of 2011 regulates that the Discussion on the Draft Law on the Establishment of Government Regulations in lieu of the Act carried out through the same mechanism as the discussion of the Draft Law and Discussion on the Draft Law on Revocation of Government Regulations in lieu of the Act carried out through a special mechanism that is excluded from the discussion mechanism of the Draft Law. ${ }^{27}$

${ }^{25}$ Article 52 paragraph (3) of Law 12 of 2011.

${ }^{26}$ Article 71 of Law 17 of 2014 letter a and letter $\mathrm{b}$.

27 Article 71 Paragraph (3) of Law 12 of 2011 regulates Provisions regarding special mechanism as referred to in paragraph (2) implemented with the following procedures: $a$. Draft Law on Revocation of Government Regulations in lieu of Acts submitted by the Parliament or the President; b. The Draft Law on Revocation as referred to in letter $a$ is submitted at the DPR Plenary Session, which does not give approval on Government Regulations in lieu of the Law proposed by the President; and c. Decision making approval for the Draft Law on Revocation as referred to in letter $b$ is carried out in the DPR Plenary Session which is the same as the plenary meeting of the determination not to give 
In the concept of article 52 and Article 71 of Law 12 of 2011, the form of approval is done by ratifying the Draft Law on the stipulation of Government Regulations Substituting Laws into Laws. So that the ratification causes the entire regulation to automatically apply.

The concept is

further technically regulated in appendix II number 239.UU 12 of 2011, which reads the body of the Law concerning the Establishment of Government Regulations in lieu of Laws (Perpu) into Acts basically consists of 2 (two) articles, which written in Arabic numerals, which are as follows:

a. Article 1 contains the stipulation of Perpu into Law which is followed by a statement attaching the Perpu as an

inseparable part of the stipulation

Law.

b. Article 2 contains provisions regarding when it comes into force.

With this form raises several legal issues, namely what if there are articles that conflict with the 1945 Constitution of the Republic of Indonesia, not synchronize with other laws or have political problems. Then the article will automatically apply because the concept of sharpening is done by the mechanism of a "package" in the Perpu.

With the concept of the regulation, the DPR does not appear to have full legislative authority as stipulated in Article 20 paragraph (1) of the 1945 NRI Constitution that the House of Representatives holds the power to form laws. And in paragraph (2) of the 1945 Constitution of the

approval to the Government Regulation in Lieu of the Law.
Republic of Indonesia Every draft law is discussed by the House of Representatives and the President for mutual agreement.

In the discussion of the Perpu it appears that the DPR cannot perform its maximum role to make improvements or cancel articles that are considered problematic ( constitutional or political). Whereas The content of Government Regulation in Lieu of Law Act together with the substance of the Act as set out in Article 11 of Law 12 of 2011 , that is set substanis same. ${ }^{28}$ But the DPR is limited in making corrections to the roubled Article. So that the House of emotion s forced to accept the whole "Discount" or not at all.

That perpu issued for "exposures crunch that force" that need to be immediately set up by the government would be able to understand. But whether because the conditions are so perpu authority of Parliament in criticizing Article in a regulation has been lost? The author believes not. Because the authori ty of the House of Representatives has a good attitude in ratifying the Perpu and also the contents in the Perpu (Article). And philosophical Act is one of the forms of social contract between the people and the government to carry out its duties. Parliament is representative of the people as a form of closers with democration representation.

${ }^{28}$ Article 10 paragraph (1) of Law 12 of 2011. Material content that must be regulated by Law contains: a. further arrangements regarding the provisions of the 1945 Constitution of the Republic of Indonesia; b. the rule of an Act to be regulated by an Act; c. ratification of certain international agreements; follow-up on the decision of the Constitutional Court; and / or fulfillment of legal needs in the community. 
JimlyAsshidiqie outlines with bo

th patterns of relationship that the people and government as well as the role of Parliament as an institution of the legislature. According to Jimly Asshiddiqie, the role of institutions legislative greatly determines that means the role of the representatives of the people elected and represent the interests of sovereign people where the sovereignty of the

State comes highly determine the validity and power belt laws it to the public. $^{29}$

Jimly Asshiddiqie then explaine $\mathrm{d}$ that the government as the party that gets the mandate kepecayaan to carry out the task - the task of government State is not allowed to download e Blocking

Reception himself all things related to policies state that will bind the citizens of the State with the burden of the obligation that is not agreed upon by their own, either concerning freedom (liberty), the principle of equality (equity), or ownership ( property) which concerns

the interests of the people. $\mathrm{J}$ ika if only policy of the State that weigh on people then the people should express approval through intermediary representatives in the institutions of the legislature. Because the policy state it must be stated in the form of law as a product of legislative (legislative act $)^{30}$

$$
\text { By since the approval }
$$

of

Parliament on a is the step involvement of the people on perpu it and forms the binding of the people on perpu. If the

${ }^{29}$ Asshiddiqie, Jimly., Perihal UndangUndang. (Jakarta: PT Raja GrafindoPersada, 2010). p. 21.
DPR has limited authority, it will cause the loss of half the authority of the people delegated to the DPR.

\section{Strengthening of DPR Legislative Authority in Perpu Approval}

As has

been explained previously that the condition of "crunch that forced" lead the government later issued a regulation, and the decision of the Court has outlined 3 reasons in issuing perpu are to be the basis of objectivity of the government for issuing a regulation one of only condition the situation is urgent need to resolve the problem the law quickly based on the Law. But if the condition of the stretcher can be constitutional reason in reducing the authority of the House of Representatives would not be justified. By because it is there are some things that need to be considered are:

1. Giving the certainty of the law are still to provide space for the Parliament to carry out its authority in accordance with Article 20 of the Constitution NRI 1945 with a maximum especially in discussing, change, and abolish the article that are considered problematic.

2. A regulation as a response on the condition that forces require certainty of law quickly so that the necessary limitations of a short time and not long as laws are commonplace.

$$
\text { With the consideration }
$$
that it should be setting the Agreement a regulation by the way: first, give the authority the Parliament to reject and accept perpu, if it accepts there are two things that can be done by the Parliament, be possible there Act attestation perpu were also set aside the 


\section{LAW REVIEW E-ISSN:2722-3663

consent but also delete / modify an article in a regulation such. With this mechanism, the DPR is no longer "forced"

all articles. Conditions

to accept

have also

pushed deeper

connection both

between the

government and

Parliament. So as to prevent bypass behavior by the government if you want to regulate something without the need for in- depth discussion with the Parliament.

Secondly, d ith the strengthening of the authority of legislation that it will have an impact on the limitation of time of approval, which no longer given in the past the trial next because very dependent with a recess in the House agenda. Should be given the limits of time by using the day to be able to provide benchmarks measure time more firmly because the conditions were very urgent that and limit the time the House of Representatives to discuss and promptly take a stance. For example 30 days or 40 days.

\section{CONCLUSION}

Settings Article 52 and Article

71 of Law 12 of

2011 unconstitutional because

it reduces the authority of the Parliament in Article 20 of the Constitution NRI 1945, the House only to approve or reject a

regulation entirely. Padaha 1 can only pe rpu accepted but Article specified in rejected or modified. Perpu can be used President to by pass the discussion in parliament in policy formation. So that the executive and legislative relations take place in a confrontational manner. The president's power in the legislative field (Perpu) has made the president a party making policy initiatives and even controlling the agenda in the legislature. The authority legislation Parliament is one of the manifestation of sovereignty of the people with the stem of representation, so that the House must has the authority same as the establishment of the Act other. Need to change the mechanism of approval by the Parliament of a regulation is to give authority to the Parliament to reject and accept perpu, if it accepts there are two things that can be done by the Parliament is receiving as a whole or accept the change / clicking abolish several chapters in perpu so that in the future may be possible there is a Law Invite endorsement perpu were also set aside the consent but also delete I modify an article in a regulation such. By because it is advisable to undergo a change in the setting of the Contracting Parliament on a regulation that stipulated in Act 12 of 2011.

\section{REFERENCES}

Arsil, Fitra., Teori Sistem Pemerintahan: Pergeseran Konsep dan Saling Kontribusi Antar Sistem Pemerintahan di Berbagai Negara, Depok: Rajawali Press, 2017.

Arsil. Fitra., Menggagas Pembatasan Pembentukan Dan Materi Muatan Perppu: Studi Perbandingan Pengaturan dan Penggunaan Perppu di NegaraNegara Presidensial, Jurnal Hukum \& Pembangunan, 48. No. 1, Fakultas Hukum Universitas Indonesia, (2018).

Asshiddiqie, Jimly., Perihal UndangUndang, Jakarta: PT Raja GrafindoPersada, 2010.

Marzuki. Peter Mahmud., Penelitian Hukum, Jakarta: Kencana Prenada Media Group. 2005. 


\section{NOMOI}

\section{LAW REVIEW E-ISSN: 2722-3663

Soekanto. S. Mamudji. S., Penelitian Hukum Normatif. Jakarta: Raja GrafindoPersada. 2006.

Yuliani, Andi., Artikel Hukum Tata Negara dan Peraturan Perundang-undangan Peraturan Pemerintah Pengganti UndangUndang dari masa ke masa, http://ditjenpp, kemenkumham,go ,id/htn-dan-puu/3000-peraturanpemerintah-pengganti-undangundang-dari-masa-kemasa,html, accessed on 18 May (2020).

Law No. 12 of 2011 concerning the Formation of Legislation.

Law No. 17 of 2014 concerning the People's Consultative Assembly, the People's Representative Council, the Regional Representative Council, and the Regional People's Representative Council.MK Decision Number 003 / PUU-III / 2005.

Decision of the Constitutional Court Number 138 / PUU-VII / 2009. 